Article

\title{
Flux of Inorganic Carbon as Dissolved, Suspended, and Bed Loads through a Karstic Basin
}

\author{
Randall Paylor and Carol Wicks *(1) \\ Department of Geology \& Geophysics, Louisiana State University, Baton Rouge, LA 70803, USA; \\ randallpaylor@gmail.com \\ * Correspondence: cwicks@lsu.edu
}

Received: 27 February 2019; Accepted: 15 March 2019; Published: 28 March 2019

\begin{abstract}
Most studies of carbonate bedrock weathering have focused on the dissolved inorganic carbon (DIC) flux while dismissing particulate inorganic carbon (PIC) as insignificant. However, under certain flow conditions PIC flux may be an important term in carbonate weathering. In this study, the total inorganic carbon (TIC) flux was calculated in a fluviokarst basin. Water samples and in situ data loggers were used to determine suspended sediment concentration and water chemistry. The mass of PIC within suspended sediments was quantified by cation/anion analysis of dual filtered/unfiltered samples. The flux of bed load material was calculated via stream power calculations. The analysis of recorded storm events indicated that PIC flux is moderate but can be significant during peak storm discharges. A small storm with a 0.87 -month return period produced a PIC flux of $14 \mathrm{~g} \mathrm{~s}^{-1}$ and a DIC flux of $150 \mathrm{~g} \mathrm{~s}^{-1}$ at $1.4 \mathrm{~m}^{3} \mathrm{~s}^{-1}$ discharge. The largest storm had a return period of 7.7 months, a peak discharge of $4.6 \mathrm{~m}^{3} \mathrm{~s}^{-1}$, and peak PIC flux of $620 \mathrm{~g} \mathrm{~s}^{-1}$ compared to a peak DIC flux of $350 \mathrm{~g} \mathrm{~s}^{-1}$. During storm events, bed load was the most significant component of the total PIC flux, exceeding the suspended load flux by an order of magnitude. When calculated on an annual basis, the data show that PIC contributes about 10 percent to total inorganic carbon removal.
\end{abstract}

Keywords: suspended load; dissolved load; bed load; inorganic carbon; karst; cave stream

\section{Introduction}

Nearly all past research on understanding the flux of carbon in karst waters has focused on the flux of dissolved inorganic carbon (DIC) [1-5]. Researchers generally assume that chemical dissolution processes dominate and that the mechanical removal of carbonate is negligible [6,7]. While chemical loads typically dominate karst waters during low to moderate flow conditions, some research has shown that the particulate inorganic carbon (PIC) in suspended and bed loads can be a major component of carbon mass flux under higher flow conditions during moderate to extreme storm events [8,9]. In addition, studies of karst landscape denudation that focus solely on dissolved components do not account for carbonate loss by removal of both fine-grained $(<62.5 \mu \mathrm{m}$; suspended load) and large ( $>62.5 \mu \mathrm{m}$, bed load) particulates. Thus, in many karstic settings, the amount of carbonate material removed may be underestimated.

In karstic basins, the transport of sediment occurs during punctuated events, such as storm flow or cover collapse $[10,11]$. Earlier work has found that runoff events that exceed certain thresholds can produce a significant flux of particulate carbonate at karst springs [9]. In certain rare flood events, some karst systems have been observed to move massive amounts of sediment as bed load or subsurface debris flows [11,12]. The objectives of this study were to quantify the total inorganic carbon flux (dissolved, suspended, and bed loads) from a karstic basin and to assess the importance of the component (dissolved, suspended, and bed) loads to the total. 


\section{Materials and Methods}

\subsection{Research Area}

The research area was Sunnybrook Blowing Cave (BC) basin in Kentucky (Figure 1). Pennsylvanian conglomerates, sandstones, and shales and Mississippian limestones and dolostones of the Cumberland Plateau underlie the forested $5.8-\mathrm{km}^{2} \mathrm{BC}$ basin. The cave system and the cave stream are formed in the Monteagle and St. Louis limestones [13]. The typical wet season for the region occurs from January through May, although precipitation from summer thunderstorms can cause intense recharge events. The surface streams that sink into the subsurface form the cave stream (allogenic recharge) [14], and thus the cave stream drains the high-relief Cumberland Plateau and is sediment rich.

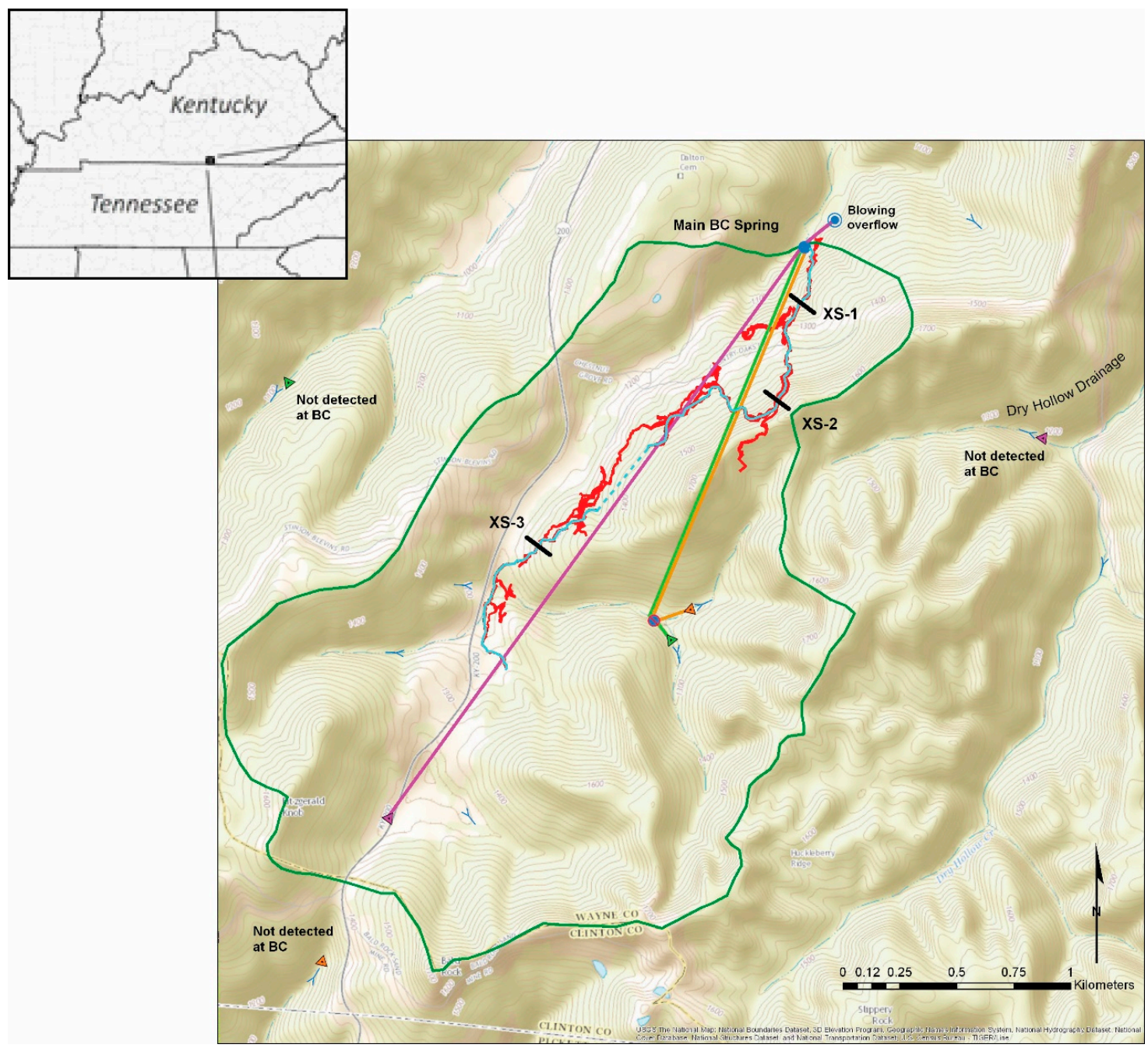

Figure 1. Index map showing Kentucky and Tennessee with black box showing location of Blowing Cave (BC) basin. Map shows outline of basin (green), cave stream (blue), cross sections (XS-1, XS-2, and XS-3), other cave passages (red), dye traces (straight magenta, yellow, and green lines), and dye injection points (triangles) with notation about recovery. Base maps provided by Kentucky Geological Survey, USGS basemap, and Kentucky Speleological Survey. Approximate location of Main BC Spring is 36.647 and -84.971 .

To estimate the conditions necessary to mobilize sediment of a variety of sizes, three locations with varying stream slopes and sediment-size distributions were selected. At each location, cross sections and grain-size distributions were measured. Stage and velocity of the water were measured using a Sontek IQ Standard acoustic Doppler velocity/stage logger (Sontek, San Diego, CA, USA) with 
a ten-minute sampling interval. The Doppler logger automatically calculated discharge at 10-minute intervals from stage, velocity, and data from the surveyed cross section. In addition, staff gauges were installed at key locations to calculate stage-discharge relationships.

At each of the three locations, the composition and the length of the intermediate axis of the particles within the streambed sediment were determined using photographic and sieving methods. Using field-scaled photographs and the geometric analysis tool in geographic information software [15], the lengths of the intermediate axis of between 250 and 500 individual particles were measured at each cross section. From these data, $D_{50}$ and $D_{84}$ were calculated where $D_{50}$ is the diameter of the particle for which $50 \%$ of the diameters of the other particles are smaller than, and $\mathrm{D}_{84}$ is the diameter of the particle at which $84 \%$ of the diameters of the other particles are smaller than. The composition of each individual particle was evaluated from the photographs or from petrographic microscopy. For the smaller sized fractions ( $<4$ phi), samples of streambed sediment were collected, weighed, dried, and sieved, and the percentage carbonate material was determined by Empyrean PANalytical XRD (Malvern PANalytical, Royston, United Kingdom) and found to be less than $2 \%$.

\subsection{Determination of the Flux of Inorganic Carbon}

\subsubsection{Inorganic Carbon as Dissolved Load}

Sampling for dissolved load involved collection of grab samples across the duration of a storm event as well as during low-flow conditions (Table S1). When necessary, ISCO automatic water samplers (Teledyne ISCO, 6712C, Lincoln, NE, USA) were deployed at the three locations to sample during high-flow events. Cation samples were treated with trace-metal grade nitric acid (Sigma-Aldrich, St. Louis, MO, USA, 70\%) after collection, and all samples were placed on ice for transport and laboratory analysis. Concentrations of $\mathrm{Cl}^{-}, \mathrm{NO}_{3}{ }^{-}$, and $\mathrm{SO}_{4}{ }^{2-}$ were analyzed using ion chromatography (Dionex, ICS-900, Sunnyvale, CA, USA), and concentrations of $\mathrm{Ca}^{2+}$, $\mathrm{Mg}^{2+}, \mathrm{Na}^{+}$, and $\mathrm{K}^{+}$were analyzed using a inductively coupled plasma (ICP) optical emission spectrometer (PerkinElmer, Avio220, Boston, MA, USA). Alkalinity was measured by titration in the field using a digital titrator with standard acid cartridges (Hach, 2272800, Loveland, CO, USA). Field parameters were measured both manually and automatically, and included field-calibrated $\mathrm{pH}$, specific conductance ( $\mathrm{SpC}$ ), temperature (T), and turbidity (NTU). Charge balance error was calculated.

A multi-parameter water quality recorder (YSI 6910, YSI, Yellow Springs, OH, USA) was programmed for a fifteen-minute sampling interval. Data from the water quality recorder were downloaded every six to eight weeks, and the probes were recalibrated and cleaned as needed. Manual measurements with handheld field probes (YSI 63, Yellow Springs, OH, USA) were also taken on each trip to verify and calibrate the data logger. Both the water quality recorder and the acoustic velocity/stage recorder were deployed in a perennially wet and uniform reach of the main cave stream approximately $0.8 \mathrm{~km}$ upstream of the lower entrance (study reach 1). For the multi-parameter water quality recorder, instrument drift between calibrations was adjusted with regression corrections.

The flux of DIC was calculated based on the proven observation that the concentrations of dissolved $\mathrm{Ca}^{2+}$ and $\mathrm{Mg}^{2+}$ ions in natural waters of karst aquifers are derived almost exclusively from the dissolution of limestone and dolomite [16]. Continuous direct analysis of $\mathrm{HCO}_{3}{ }^{-}, \mathrm{Ca}^{2+}$, and $\mathrm{Mg}^{2+}$ was prohibitive because of the necessity for hundreds of field titrations or for hundreds of water samples. Therefore, the measured continuous specific conductance (SpC) from the YSI water quality recorder was correlated to concentrations of dissolved species from a single storm event that was sampled with a high temporal resolution. This correlation was applied across the remaining temporal record.

\subsubsection{Inorganic Carbon as Suspended Load}

In order to determine PIC flux in suspended loads, three types of data were collected and correlated: a continuous time series record of turbidity, measurements of total suspended sediment 
(TSS), and the amount of carbonate in the suspended sediment. The optical turbidity probe-which was calibrated with formazin standards-on the YSI-6910 logger recorded time series turbidity measurements. The YSI-6910 was installed so that the turbidity probe was at 0.5 depth of water under most conditions.

TSS was measured over a range of conditions by collecting $500 \mathrm{~mL}$ grab samples with an ISCO automatic sampler every $30 \mathrm{~min}$ for a span of $12 \mathrm{~h}$ during the December 2012-January 2013 storm event, during the 13 July 2013 storm event, and by collecting additional grab samples under low-flow conditions. Because water depths were generally less than $1 \mathrm{~m}$, grab samples for TSS and determining the amount carbonate in the suspended sediment were taken by moving the sample bottle from the surface to near the streambed and back. These samples were filtered in the laboratory and the filtrate was dried and weighed for TSS mass. The measured mass was used to convert turbidity time series data to the mass of total suspended sediment.

The PIC fraction of the TSS was determined by analyzing calcium and magnesium cations between pairs of acidified filtered ( $0.45 \mu \mathrm{m}$ Millex-HA, Millipore-Sigma, Burlington, MA, USA) and unfiltered samples, and was adopted for the rest of the study period. The precision of the ICP lab analysis allowed differences of less than $+/-0.5 \%$ in $\mathrm{Ca}^{2+}$ and $\mathrm{Mg}^{2+}$ to be determined in most cases. The filtered and unfiltered grab samples were acidified to $\mathrm{pH} 2$ with trace-metal grade nitric acid to dissolve particulate carbonate. These samples were analyzed for differences in $\mathrm{Ca}^{2+}$ and $\mathrm{Mg}^{2+}$ since in typical karst waters, cations are derived almost exclusively from carbonate [16]. The amount of PIC in the suspended load was the difference between the filtered and unfiltered samples. Paired cation analysis of filtered and unfiltered samples proved to be a better method for assessing excess PIC in suspended sediment.

Although dissolved carbonate loads can be calculated exclusively from $\mathrm{HCO}_{3}{ }^{-}$concentrations, $\mathrm{pH}$, temperature, and carbonate equilibrium constants, a better method was used that calculates contributions from limestone and dolostone dissolution in karst systems using concentrations of $\mathrm{HCO}_{3}{ }^{-}, \mathrm{Ca}^{2+}$, and $\mathrm{Mg}^{2+}$ ions. Calculated $\mathrm{HCO}_{3}{ }^{-}$concentrations derived from field titrations resulted from an advanced speciation model that incorporated initial $\mathrm{pH}$ and the temperature-dependent Debye-Hückel activity coefficient calculations and temperature-dependent equilibrium relationships. $\mathrm{pCO}_{2}$ is accounted for in the calculation, and of the remaining dissolved carbon species, $\mathrm{HCO}_{3}{ }^{-}$was $>99.2 \%$ of the total in all tested samples.

\subsubsection{Inorganic Carbon as Bed Load}

The bed load transport rate, $\mathrm{q}_{\mathrm{b}}$, was determined from the transport function that is a derivation of Bagnold's original formula:

$$
\mathrm{q}_{\mathrm{b}}=\left(\omega-\omega_{0}\right)^{3 / 2}\left(\mathrm{D}_{50}^{1 / 4} / \mathrm{d}\right)\left(1 / \rho_{\mathrm{r}}^{1 / 2} \mathrm{~g}^{1 / 4}\right)
$$

where $d$ is the water depth, $D_{50}$ is the length of intermediate axis of $\rho_{r}$ which is the rock density in water, $g$ is gravity, $\omega$ is the unit stream power (Equation (2)), and $\omega_{0}$ is the critical unit stream power (Equation (3)) [17]. The unit stream power is:

$$
\omega=\frac{\rho_{\mathrm{w}} \mathrm{gQS}}{\mathrm{b}}
$$

where $\rho_{\mathrm{W}}$ is the density of water, $\mathrm{S}$ the energy slope (estimated as the measured slope of the streambed), $\mathrm{Q}$ is stream discharge (obtained from time series data of the velocity and depth of water), and $\mathrm{b}$ is the width of the active channel. The critical unit stream power, $\omega_{0}$, was determined from [18]:

$$
\omega_{0}=0.104 \frac{D_{b}^{1.5}}{S^{0.17}}\left(\frac{D_{i}}{D_{b}}\right)^{0.67}
$$

where the overall bed material size is $D_{b}$ (in this study, $D_{50}$ was used) and the grain size of interest is $D_{i}\left(D_{84}\right.$ in this study). Movement of the bed load is predicted to occur when $\omega$ exceeds $\omega_{0}$. The bed 
load flux at each station (Equation (1)) was multiplied by the percentage of carbonate material in the bed load to determine the load of PIC. The average of the fluxes at the three locations was determined.

Numerous empirical bed load entrainment and transport formula have been utilized for surface stream studies [19-27]; however there have been few studies of bed load entrainment in cave streams [28-30]. Thus, the value of the constant in Equation (3), which depends on Reynolds number, slope, ratio of $D_{\max } / D_{50}$, and is related to the Manning-Strickler resistance [31], should be evaluated prior to its application to a cave stream. Field observations of the initiation of bed load movement as indicated by the movement of tracers were made. The value of the constant was estimated from the stream power at the time that bed load movement was initiated. In addition, several hundred cobbles and boulders from the cave stream were tagged with radio-frequency identification (RFID) chips and also painted and numbered and deployed at XS-1 and XS-2. The mass of the tracers that were moved during particular floods was compared to calculated mass expected to move calculated using Equations (1)-(3). The value of the constant in the critical unit shear stress equation (Equation (3)) was adjusted until the calculated flux of bed load (Equation (1)) equaled the measured flux of the tracers.

\section{Results}

\subsection{Field Data}

The record of logger data at Blowing Cave spans a period from 10 November 2012 to 27 October 2013 (Figure 2). In the Sontek measured flow data, there are both smaller and larger gaps: 15-23 January, 30 March-5 April, 2-14 July, 3-27 August, and 15 April to 29 May, respectively (blue line in Figure 2). For the smaller gaps, discharge data were filled in using a correlation between the stage recorded by the YSI Sonde and stage recorded by the Sontek (the correlation was based on all data for which each instrument recorded stage; Figure S1). That correlated stage was then converted to discharge using the same technique as was used for all other stage data recorded by the Sontek. For the larger gap, discharge data were filled in using a correlation between discharge measured with the Sontek and discharge measured at the nearest US Geological Surface gauging station (correlation based on Beaver Creek, USGS 03413200 record for 13 January 2013 for which 30-minute discharge data were available; Figure S2).

$\mathrm{SpC}$ values ranged from $113-305 \mu \mathrm{sm}^{-1}, \mathrm{~T}$ from $9.9-17.3^{\circ} \mathrm{C}$, and $\mathrm{pH}$ from 7.2-8.4. Flow was extremely variable and flashy and ranged from a low of less than $0.004 \mathrm{~m}^{3} \mathrm{~s}^{-1}$ during the dry season to $4.42 \mathrm{~m}^{3} \mathrm{~s}^{-1}$ at the largest storm flow that occurred in early August 2013, a difference over three orders of magnitude. The data demonstrate a strong, rapid response to rain events and a small seasonal component of increased base flow and lower $\mathrm{SpC}$ and turbidity during winter. TSS typically peaked just before or at peak discharge, reaching a maximum storm value of $635 \mathrm{mg} \mathrm{L}^{-1}$ during the August 2013 event. TSS was very low between both summer and winter storms, averaging less than $12 \mathrm{mg} \mathrm{L}^{-1}$.

At $\mathrm{BC}$, there is a clear progression in bed load grain size from larger particles at the upstream end (cross section, XS) to smaller particles nearer the downstream cave outlet (XS-1) (Table 1). The streambed material consists of silt to large boulder material. Additional channel parameters needed for calculating hydraulics and running models were measured at each site.

Table 1. Values of parameters measured at each the three locations in Blowing Cave, Kentucky.

\begin{tabular}{cccccccc}
\hline Location & $\begin{array}{c}\text { Channel } \\
\text { Width (m) }\end{array}$ & $\begin{array}{c}\text { Channel Slope } \\
\left(\mathbf{m m}^{-1} \mathbf{)}\right.\end{array}$ & $\mathbf{D}_{\mathbf{5 0}} \mathbf{( m m )}$ & $\mathbf{D}_{\mathbf{8 4}} \mathbf{( m m )}$ & $\begin{array}{c}\text { Carbonate in } \\
\text { Bed Material }\end{array}$ & $\begin{array}{c}\text { Channel } \\
\text { Classification }\end{array}$ & $\begin{array}{c}\text { Critical Stream } \\
\text { Power } \\
\text { (Equation (3)) }\end{array}$ \\
\hline XS-1 & 4.31 & 0.008 & 18 & 43 & $7 \%$ & Plane bed \\
XS-2 & 4.10 & 0.005 & 25 & 75 & $13 \%$ & $\begin{array}{c}\text { Pool/Riffle } \\
\text { Plane bed }\end{array}$ \\
XS-3 & 3.80 & 0.012 & 50 & 105 & $16 \%$ & 66.8 \\
\hline
\end{tabular}




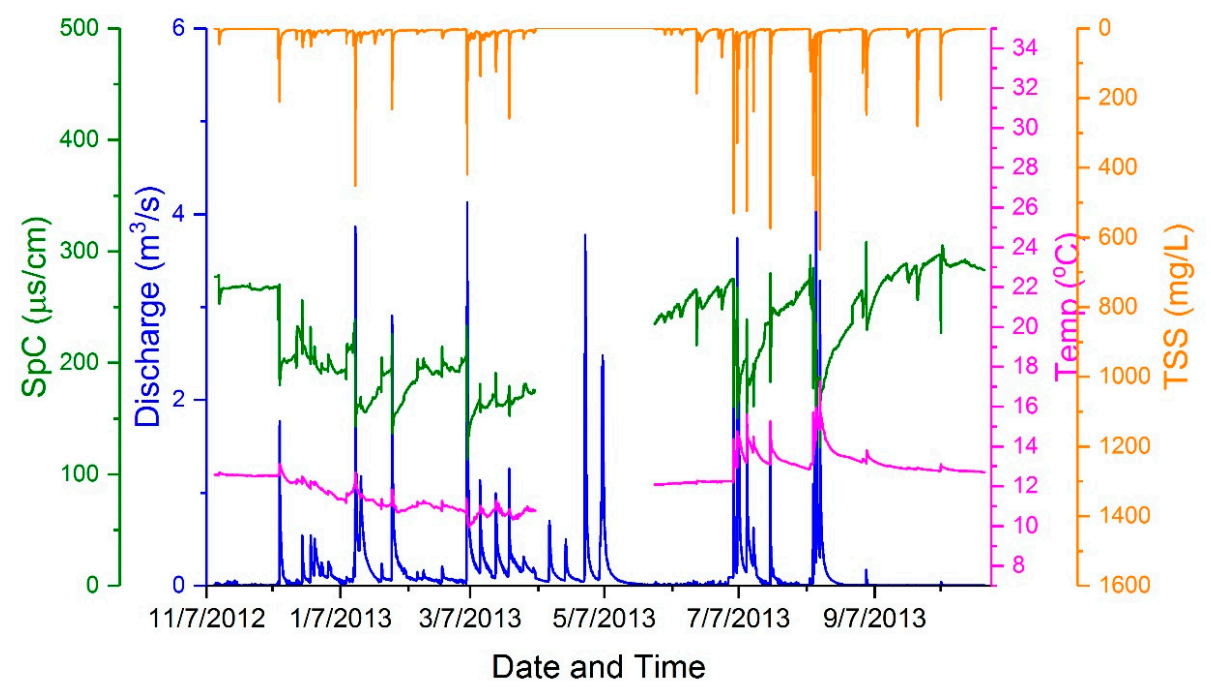

Figure 2. Time series data for Blowing Cave, Kentucky. Discharge record is continuous from November 2012 to October 2013. Water quality data include two continuous runs with a 7-week gap (TSS data is reversed for clarity).

\subsection{Dissolved Flux}

To construct the time series dataset for dissolved carbonate in BC (Figure 3), regressions were calculated between $\mathrm{SpC}$ data and $\mathrm{Mg}^{2+}, \mathrm{Ca}^{2+}$, and $\mathrm{HCO}_{3}{ }^{-}$concentrations. The slope of the regressions were all positive since higher concentrations of dissolved constituents results in higher $\mathrm{SpC}$ levels. The correlation coefficients for the regressions were statistically significant: 0.89 for $\mathrm{HCO}_{3}{ }^{-}, 0.81$ for $\mathrm{Ca}^{2+}$, and 0.77 for $\mathrm{Mg}^{2+}$ (Figure S3). The regression equations were applied to the full $\mathrm{SpC}$ dataset and the resulting 15-minute concentrations converted to $\mathrm{mM}$ for analysis of ion ratios and calculation of the amount and types of carbonate bedrock dissolved. The calculated concentrations ranged from 1.04 to

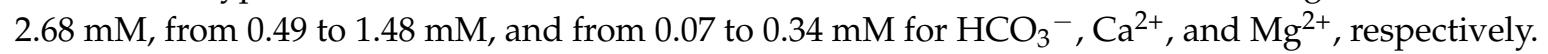

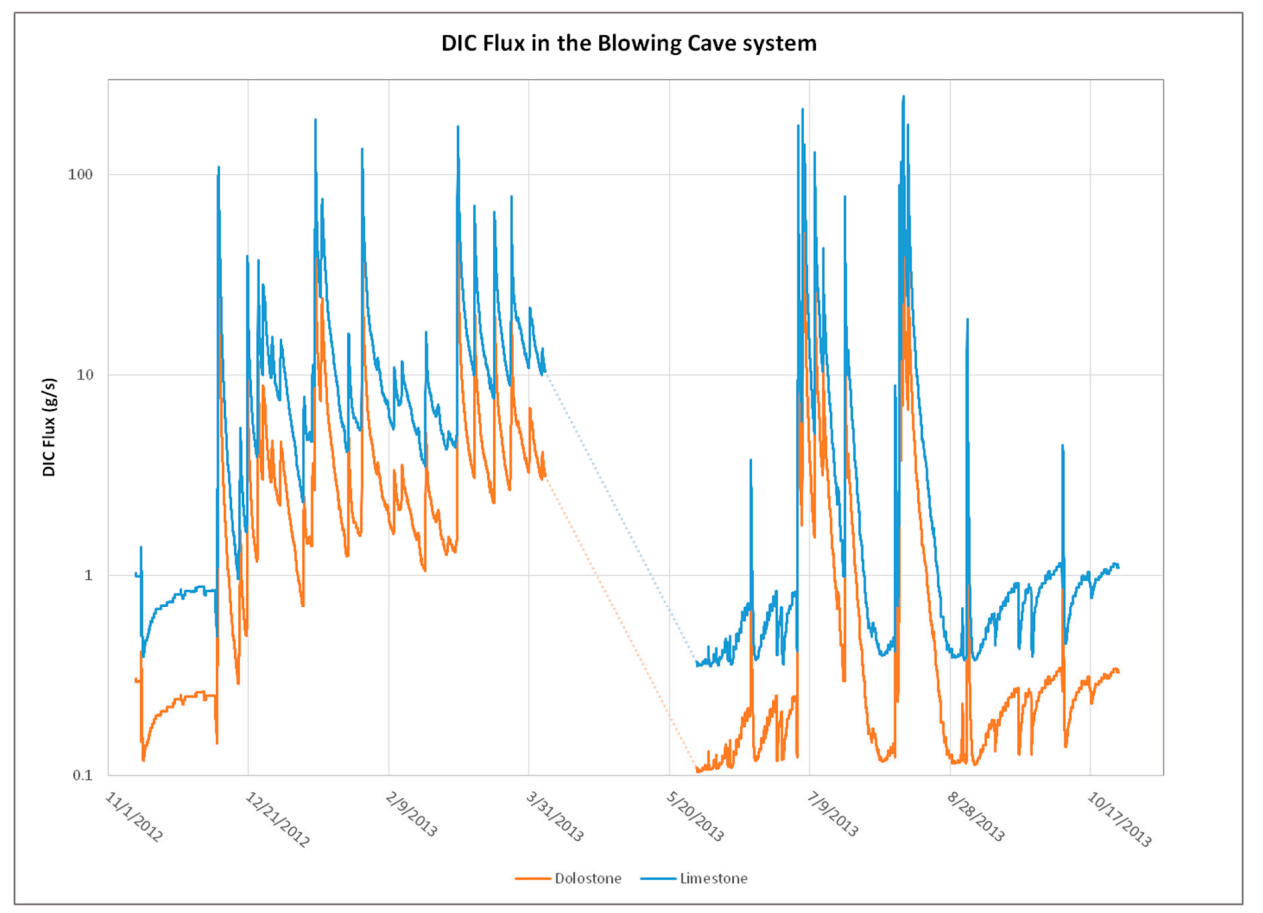

Figure 3. Flux of dissolved inorganic carbon through for the Blowing Cave Kentucky system. The gap in the modeled flux is from the lack of SpC logs from instrument downtime. 


\subsection{Suspended}

After correlating TSS to turbidity (Figure S4), the correlation was applied to the turbidity record to produce a time series record of TSS. The TSS record was portioned into PIC from limestone $(75.6 \%$ of $\mathrm{Ca}^{2+}$ and $\mathrm{Mg}^{2+}$ ) and from dolostone (24.4\% of inorganic carbon) (Figure 4). Some significant scatter occurred in the correlation of PIC to TSS and discharge because peak PIC concentrations did not always correspond to the peak TSS discharge, and more importantly, TSS typically reached a peak 15 to $45 \mathrm{~min}$ before peak storm discharge and also sometimes after.

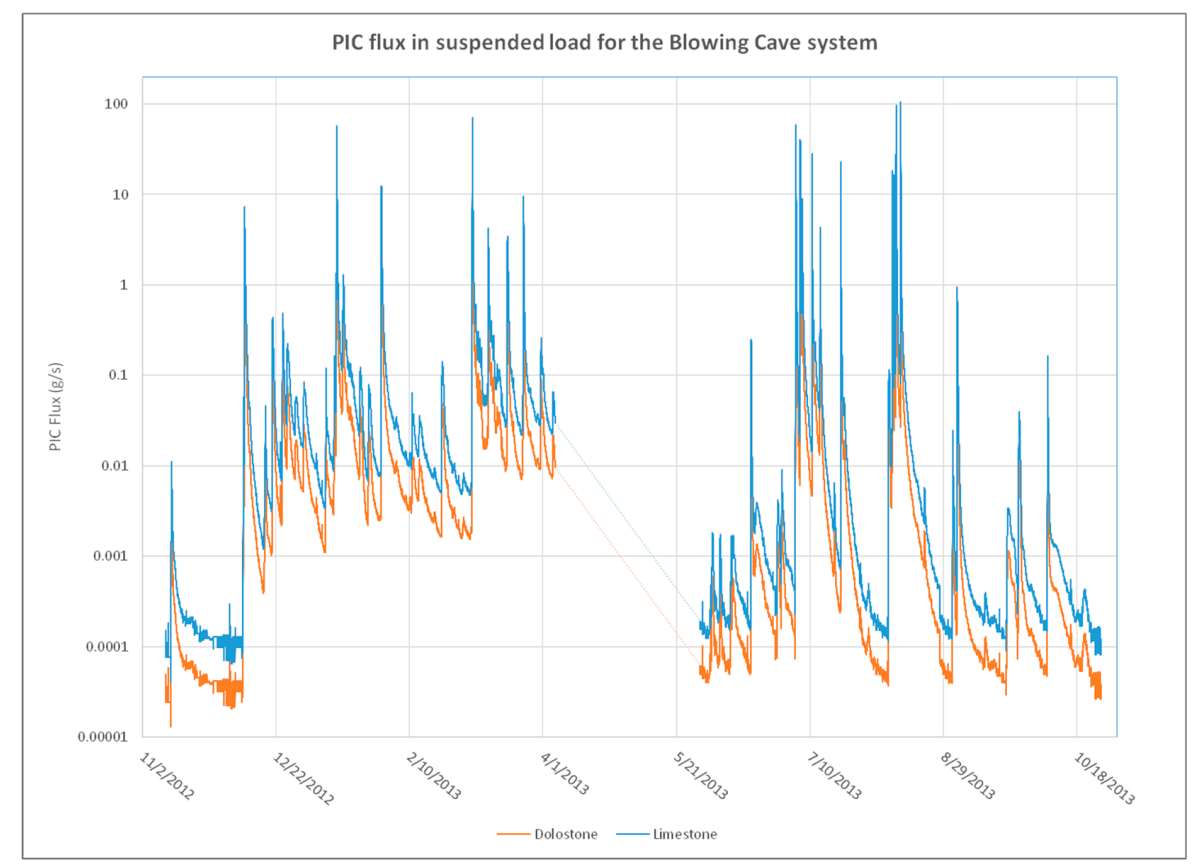

Figure 4. Flux of particulate inorganic carbon carried as a suspended load through the Blowing Cave Kentucky system. Gap in modeled flux is from lack of turbidity logs from instrument downtime.

\subsection{Bed Load Flux}

The value of the constant based on initiation of bed load movement ranged from 0.043 to 0.075 . The tracer data were collected during ten trips to measure tagged cobble movement before and after each of four different storm events at XS-1: 10 December 2012; 30 January, 28 April, and 6 July 2013, and the three latter storm events at XS-2. Based on the mass of tracers moved, the value of the constant ranged from 0.075 to 0.11 . The value of the constant was set to 0.075 for XS- 1 and XS-3, and 0.043 for XS-2.

The movement of bed material in the $\mathrm{BC}$ system is highly punctuated, appearing as short spikes (Figure 5). The highest flux of bed load occurred was $2132 \mathrm{~kg}$ of PIC moved over a 30-minute period at peak discharge during the 11 August 2013 storm. The short duration and intensity of these events shows the difficultly of accurately assessing sediment transport in flashy systems. 


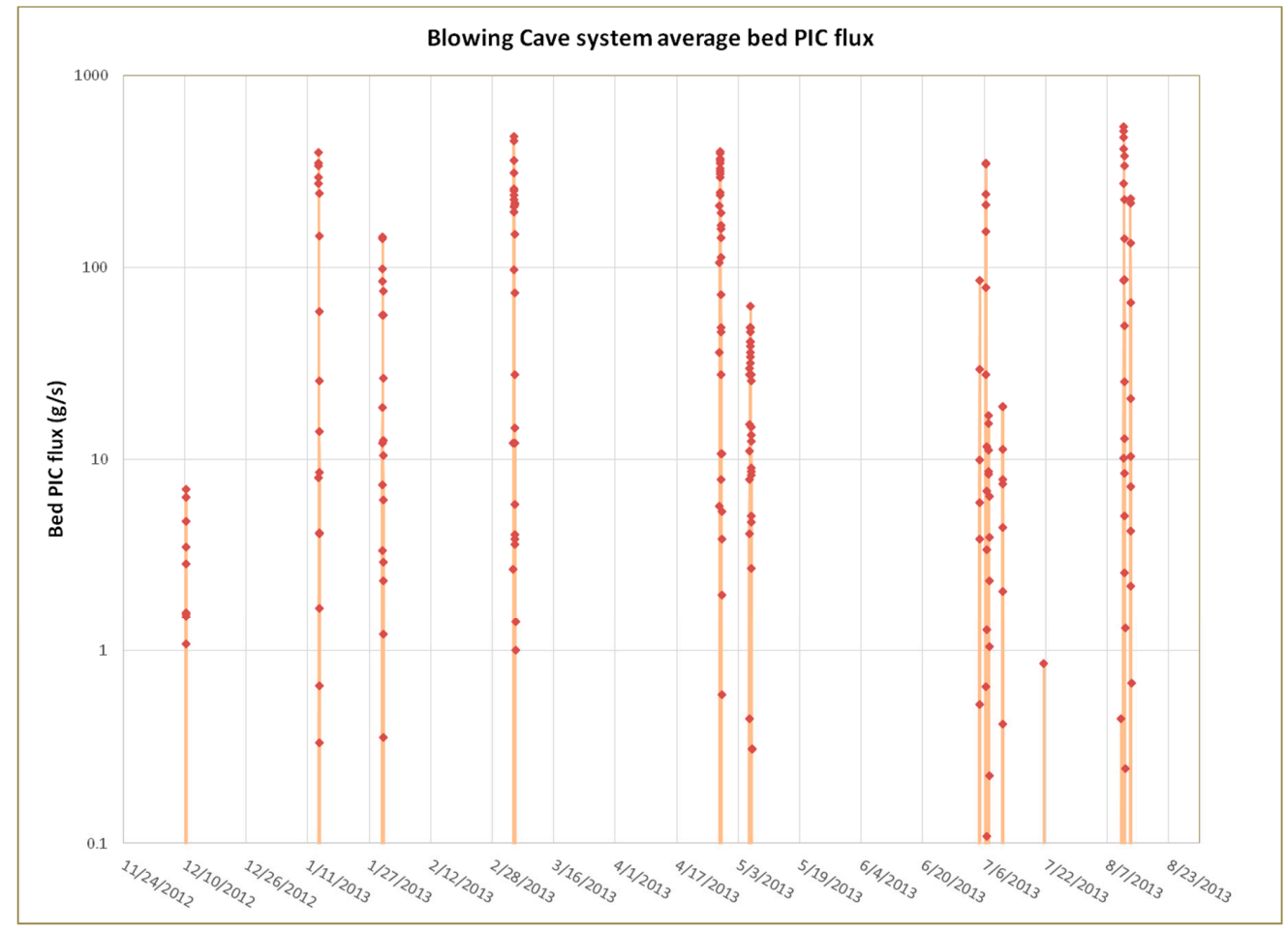

Figure 5. Flux of particulate inorganic carbon carried a bed load through the Blowing Cave Kentucky system. Flux is the average of the three modeled cross-sections representing the main channel types in the system using the constant 0.075 for XS-1 and XS-3, and 0.043 for XS-2.

\subsection{Total Inorganic Carbon Flux}

Given the laboratory error of $<3 \%$ and an unknown field error, the suspended PIC was $2.3 \%$ of the total flux, and bed load PIC was $8 \%$ of the total flux. In all, mechanical erosion of PIC made up $10.3 \%$ of the total carbon removal, with DIC making up $89.7 \%$. The removal of PIC material is highly dependent on storm events, and the study confirmed that DIC dominates carbon flux at low to moderate flow conditions. During regular storm flow, bed and suspended PIC become more significant, and at discharges of $3 \mathrm{~m}^{3} \mathrm{~s}^{-1}$ and larger, they become the dominant inorganic carbon mass removal components. At the largest recorded storm event during this study, the combined bed and suspended PIC flux was $50 \%$ larger than the DIC flux.

For the dissolved flux of inorganic carbon, the water chemistry indicates that $24.4 \%$ of the $\mathrm{Mg}^{2+}$ and $\mathrm{Ca}^{2+}$ in solution originates from dolomite dissolution. The molar results of $\mathrm{Ca}^{2+}, \mathrm{Mg}^{2+}$, and $\mathrm{HCO}_{3}{ }^{-}$can be compared to determine the ratio of bicarbonate to dissolved carbonate bedrock. If all the dissolution of the bedrock is attributable to reaction with $\mathrm{CO}_{2}$, then the $\mathrm{Ca}^{2+}+\mathrm{Mg}^{2+}: \mathrm{HCO}_{3}{ }^{-}$ratio will be $1: 2(0.5)$. In many karst settings, however, the ratio is typically $>0.5$. A ratio of 0.57 has been measured at Mammoth Cave and a ratio of 0.64 at Redmond Creek, a site just a few miles from Blowing Cave $[4,32]$. For this study, the modeled ratio ranged from 0.54 to 0.67 depending on conditions and flow. The additional bedrock corrosion may be attributable to dissolution by other compounds such as organic acids or sulfuric acid derived from oxidation of pyrite or from soil $\mathrm{CO}_{2}$. Results for the different modeled dissolved components produced a time series dataset for the DIC flux. The flux of inorganic carbon as suspended and bed load is due to bedrock dissolution.

\section{Discussion}

The removal of PIC material is highly dependent on storm events, and the study confirmed that DIC dominates carbon flux at low to moderate flow conditions (Figure 6). During high discharge events related to precipitation events, bed and suspended PIC become more significant, and at discharges 
of approximately $3 \mathrm{~m}^{3} \mathrm{~s}^{-1}$, the flux of bed load approaches that of the dissolved load. Surprisingly, the movement of carbonate via bed load transport turned out to be the most significant mechanical process in the BC system. Eleven different storm events transported bed load during the study year. Carbonate bed material is large enough to persist for long periods of time as it is continually produced by breakdown of cave walls and moved downstream, ultimately exiting the system to continue being dissolved in surface waters.

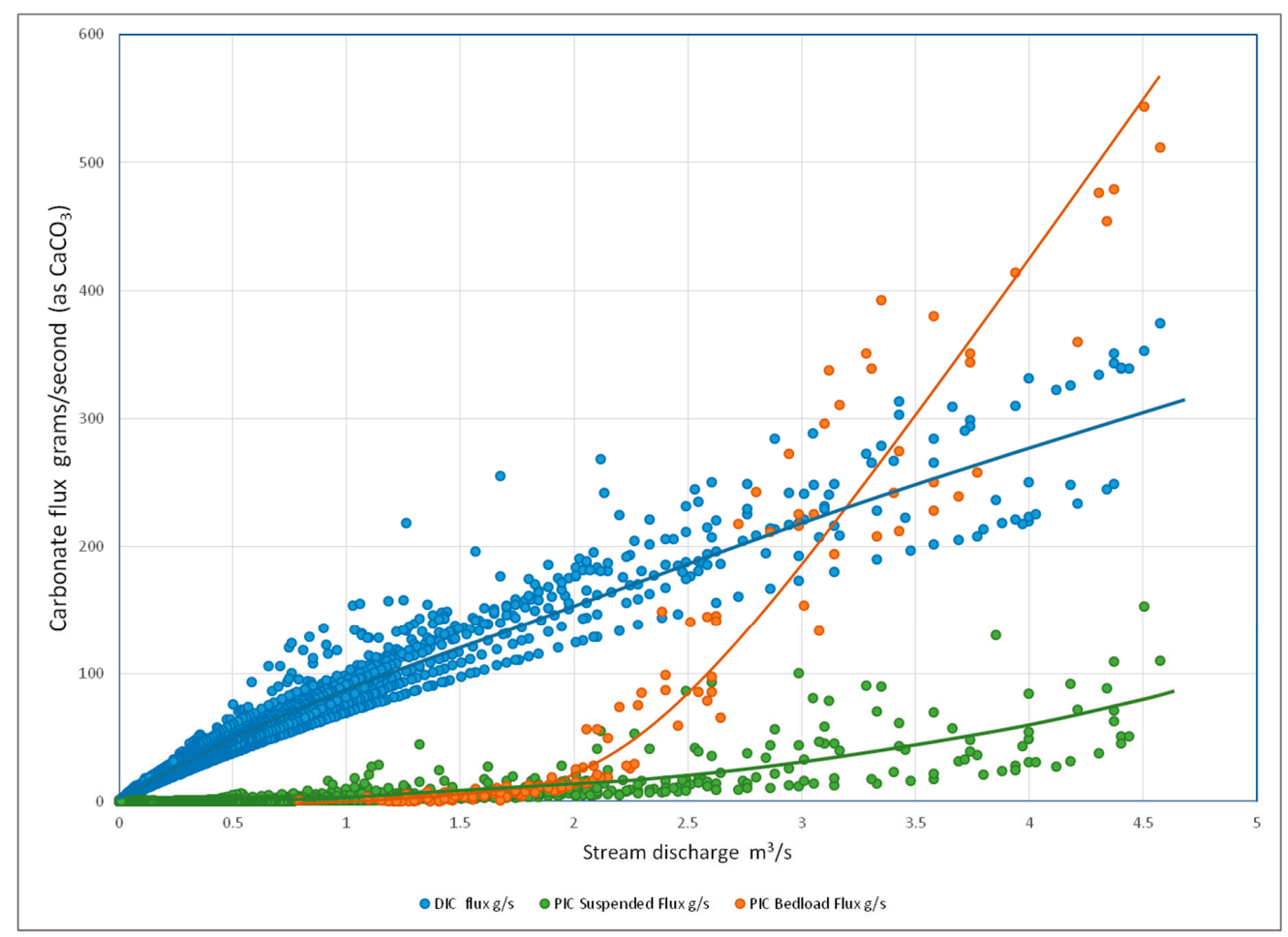

Figure 6. Comparison of flux of inorganic carbon for the Blowing Cave Kentucky system over the 2012/2013 water year.

The value of the constant is a source of uncertainty in the estimates of the flux of inorganic carbon carried as dissolved, suspended, and bed load over a year. The value of the constant was found to be equal to or less than the value of 0.104 . These smaller values result in a calculated PIC load that is $10 \%$ of the annual load. However, the calculated total PIC load while using the 0.104 value for the constant is reduced to $\sim 5 \%$ ( $2.3 \%$ suspended and $2.7 \%$ bed load). The value of the constant is dependent on surface roughness [19], which has not been documented in cave streams. Given the sensitivity of the calculations to the value of the constant, research aimed at documenting when bed load movement occurs, the value of the critical stream power at that time, and the value of the constant is needed.

The most significant limitation in this study is related to the rarity of large storm events. There is some evidence that larger infrequent storms ( $<2$ events/decade return period) radically increase the removal of sediment from the system. Before field data collection began at BC, the aftermath of a storm in 2009 was observed that left high water marks at XS-15.2 m above the streambed, over six times higher than any recorded storm for the study period. At that level, the change from open-channel hydraulics to pipe-full conditions in much of the stream can create velocities that move massive amounts of material. After the event, over $1.5 \mathrm{~m}$ of bed material had been completely removed near XS-1 and transported downstream. A more comprehensive and longer study would be necessary to capture this type of flow event. Research at BC focused on a well-defined but small basin, so extrapolation of results to a regional scale should be done with caution.

Many previous researchers have dismissed the amount of inorganic carbon that is removed from karstic basins via particulate loads (either suspended or bed loads). While this assumption might be 
valid over base flow conditions, it is not valid during storm events when bed and suspended loads approach and exceed that of the dissolved load. In addition, when estimating the long-term removal of inorganic carbon from a basin, the PIC load is $~ 10 \%$ of the total load. This value should help other researchers understand the magnitude of the error introduced when dismissing the role of movement of inorganic carbon via suspended and bed loads.

\section{Conclusions}

Particulate inorganic carbon flux was demonstrated to be a significant component of total carbon removal in the basins studied. PIC fluxes are highly dependent on storm flow and stream power, so careful evaluation of stream dynamics was necessary to adequately characterize the full mass transport, and this type of study is applicable to other areas of mixed carbonate/non-carbonate fluviokarst. Some flood events with approximately 8-month return periods have been shown to produce PIC fluxes that exceed the DIC flux by over $50 \%$. The flux of carbonate bed load was the most prominent process in PIC movement through the studied systems. The contribution of PIC to the total inorganic carbon removal for the annual study period at BC was $10.3 \%$, of which $2.3 \%$ came from suspended PIC and $8.0 \%$ came from bed load PIC. Much larger storms and more significant bed load fluxes have been observed at the study site in the past, but further monitoring would be needed to capture that data.

Supplementary Materials: The following are available online at http:/ /www.mdpi.com/2073-4441/11/4/644/s1; Figure S1: Correlation between depth measured using YSI Sonde and depth measured using Sontek Sonde; Figure S2: Correlation between discharge measured at USGS location and calculated using the Sontek Sonde; Figure S3: Correlations between concentration of major cations and specific conductance; Figure S4: Correlation between total suspended solids (TSS) and turbidity; and Table S1: regression statistics for $\mathrm{Ca}^{2+}$ and $\mathrm{SpC}, \mathrm{Mg}^{2+}$ and $\mathrm{SpC}$, and $\mathrm{HCO}_{3}{ }^{-1}$ and $\mathrm{SpC}$. Time series and discrete events sampling data are available at: https:// data. mendeley.com/datasets/kyyjv33b99/draft?a=decfe201-a876-419f-97f2-d4c126fca3e2.

Author Contributions: Author contributions were conceptualization, R.P. and C.W.; methodology, R.P.; validation, C.W.; formal analysis, C.W.; investigation, R.P.; resources, C.W.; data curation, C.W.; writing-original draft preparation, R.P.; writing—review and editing, C.W.; project administration, C.W.; funding acquisition, C.W.

Funding: This research was funded by the National Science Foundation, grant number 1141745.

Acknowledgments: The authors thank Dr. Ellen Herman and four anonymous reviewers for helpful comments on an earlier version of this manuscript.

Conflicts of Interest: The authors declare no conflict of interest. The funders had no role in the design of the study; in the collection, analyses, or interpretation of data; in the writing of the manuscript, or in the decision to publish the results.

\section{References}

1. Liu, Z.; Zhao, J. Contribution of Carbonate Rock Weathering to the Atmospheric CO Sink. Environ. Geol. 2000, 39, 1053-1058. [CrossRef]

2. Dreybrodt, W.; Eisenlohr, L. Limestone dissolution rates in karst environments. In Speleogenesis and Evolution of Karst Aquifers; Klimchouk, A., Ford, D., Palmer, A.N., Dreybrodt, W., Eds.; National Speleological Society: Huntsville, AL, USA, 2000; pp. 136-148.

3. White, W.B. Karst hydrology: Recent developments and open questions. Eng. Geol. 2002, 65, 85-105. [CrossRef]

4. Groves, C.; Meiman, J. Inorganic carbon flux and aquifer evolution in the south central Kentucky karst. In US Geological Survey Karst Interest Group Proceedings; Water-Resources Investigations Report 01-4011; Western Kentucky University: Bowling Green, KY, USA, 2011.

5. Gombert, P. Role of karstic dissolution in global carbon cycle. Glob. Planet. Chang. 2002, 33, 177-184. [CrossRef]

6. White, W.B. Rate Processes: Chemical Kinetics and Karst Landform Development; Zeitschrift fur Geomorphologie, Groundwater as a Geomorphic Agent: London, UK, 1984; pp. 227-248.

7. Palmer, A.N. Cave Geology; Cave Books: Dayton, OH, USA, 2007.

8. Newson, M.D. A Model of subterranean limestone erosion in the British Isles based on hydrology. Trans. Inst. Br. Geogr. 1971, 54, 55-70. [CrossRef]

9. Herman, E.K.; Toran, L.; White, W.B. Threshold events in spring discharge: Evidence from sediment and continuous water level measurement. J. Hydrol. 2008, 351, 98-106. [CrossRef] 
10. Bosch, R.F.; White, W.B. Lithofacies and Transport for Clastic Sediments in Karst Conduits. In Karst Groundwater Contamination and Public Health; Springer: Cham, Switzerland, 2018; pp. 277-281.

11. Van Gundy, J.J.; White, W.B. Sediment flushing in Mystic Cave, West Virginia, USA, in response to the 1985 Potomac Valley flood. Int. J. Speleol. 2009, 38, 103-109. [CrossRef]

12. Crawford, N.C. The Karst Hydrogeology of the Cumberland Plateau Escarpment of Tennessee; Tennessee Division of Geology: Knoxville, TN, USA, 1996.

13. Lewis, R.Q. Geologic Map of the Powersburg Quadrangle and Part of the Pall Mall Quadrangle, Wayne and Clinton Counties; USGS Store: Murray, KY, USA, 1977; p. 1.

14. White, W.B. Dissolution of limestone from field observations. In Speleogenesis and Evolution of Karst Aquifers; Klimchouk, A.B., Ford, D., Palmer, A.N., Dreybrodt, W., Eds.; National Speleological Society: Huntsville, AL, USA, 2000; pp. 149-155.

15. Graham, D.J.; Rice, S.P.; Reid, I. A transferable method for the automated grain sizing of river gravels. Water Resour. Res. 2005, 41, 1-12. [CrossRef]

16. Ford, D.; Williams, P.D. Karst Geomorphology and Hydrology; Unwin Hyman: London, UK, 2007.

17. Martin, Y.; Church, M. Re-examination of Bagnold's empirical bedload formulae. Earth Surf. Process. Landf. 2000, 25, 1011-1024. [CrossRef]

18. Ferguson, R.I. Estimating critical stream power for bedload transport calculations in gravel-bed rivers. Geomorphology 2005, 70, 33-41. [CrossRef]

19. Van Rijn, L.C. Sediment transport, part 1: Bed load transport. J. Hydraul. Eng. 1985, 110, 1431-1456. [CrossRef]

20. Buffington, J.M.; Montgomery, D.R. A systematic analysis of eight decades of incipient motion studies, with special reference to gravel-bedded rivers. Water Resour. Res. 1997, 33, 1993-2029. [CrossRef]

21. Ferguson, R.I.; Wathen, S.J. Tracer-pebble movement along a concave river profile: Virtual velocity in relation to grain size and shear stress transport and deposition. Water Resour. Res. 1998, 34, 2031-2038. [CrossRef]

22. Almedeij, J.H. Bedload Transport in Gravel-Bed Streams under a Wide Range of Shields Stresses. Ph.D. Thesis, Virginia Polytechnic Institute and State University, Blacksburg, VA, USA, 2002.

23. Martin, Y. Evaluation of bed load transport formulae using field evidence from the Vedder River, British Columbia. Geomorphology 2002, 53, 75-95. [CrossRef]

24. Wilcock, P.R. Entrainment, displacement, and transport of tracer gravels. Earth Surf. Process. Landf. 1997, 22, 1125-1138. [CrossRef]

25. Barry, J.J.; Buffington, J.M.; King, J.G.; Goodwin, P. Performance of bed load transport equations in mountain gravel-bed rivers: A re-analysis. In Proceedings of the Eighth Federal Interagency Sedimentation Conference (8thFISC), Reno, NV, USA, 2-6 April 2006; pp. 90-97.

26. Holmes, R.R.; Holmes, R.R.J. Measurement of Bedload Transport in Sand-Bed Rivers: A look at Two Indirect Sampling Methods; US Geological Survey Scientific Investigations Report; U.S. Geological Survey: Rolla, MO, USA, 2010; Volume 1914, pp. 236-252.

27. Turowski, J.M.; Badoux, A.; Rickenmann, D. Start and end of bedload transport in gravel-bed streams. Geophys. Res. Lett. 2011, 38. [CrossRef]

28. Dogwiler, T.; Wicks, C.M. Sediment entrainment and transport in fluviokarst systems. J. Hydrol. 2004, 295, 163-172. [CrossRef]

29. Rossman, N.R. Entrainment and Transport of Coarse Stream Bed Material in a Fluviokarst Watershed, South-Central Missouri: A Tracer Particle Study; University of Missouri: Columbia, MO, USA, 2010.

30. Wicks, C.; Noltie, D.B.; Peterson, E.W.; Dogwiler, T. Disturbances in the habitat of Macrocotyla glandulosa (Kenk). J. Ecohydrol. 2010, 125, 116-125. [CrossRef]

31. Aguirre-Pe, J.; Olivero, M.L.; Moncada, A.T. Particle densimetric Froude number for estimating sediment transport. J. Hydraul. Eng. Asce 2003, 129, 428-437. [CrossRef]

32. Florea, L.J. Carbon flux and landscape evolution in epigenic karst aquifers modeled from geochemical mass balance. Earth Surf. Process. Landf. 2015, 40. [CrossRef]

(C) 2019 by the authors. Licensee MDPI, Basel, Switzerland. This article is an open access article distributed under the terms and conditions of the Creative Commons Attribution (CC BY) license (http:/ / creativecommons.org/licenses/by/4.0/). 